\title{
The career planning of young prisoner study at Lembaga Pembinaan Khusus Anak (LPKA) Tanjung Pati
}

\author{
Elviana $^{1}$, Afdal ${ }^{2}$, A. Muri Yusuf ${ }^{3}$ \\ ${ }^{123}$ Universitas Negeri Padang, Padang - Indonesia, (elviana443@gmail.com)
}

\begin{abstract}
One of the tasks of development that must be traversed by a teenager is a task in planning or choosinga career/job for the future. However, many conditions faced by teens who were in Lembaga Pembinaan Khusus Anak (LPKA) as the Special Children's Mentoring Institute,include the lack of career information that they have caused them difficulty and have trouble doing career planning for their future. This research aims to describe of the problem of young prisoner in the career planning process. This research used quantitative approaches with descriptive-quantitative method. The sample in this research consisted of 32 young prisoner. The results showed that young prisoner who have problems of planning a career on the very high category as many as 17 people with $51.51 \%$, in high category as many as 11 people with $33.33 \%$ and on the category quite as many as 4 people with $12.12 \%$.
\end{abstract}

Keywords: career planning, young prisoner.

\section{Introduction}

Adosence is an age of transition from childhood to adulthood (Hurlock, 1999; Sarwono, 2012; Nindya \& Margaretha, 2012; Batubara, 2016) followed by changes and developments in the biological, psychological, and socio-emotional (Santrock, 1998 ; Papalia, Olds, Feldman, 2009) which takes place from the age of 10 or 11 years until early twenties (Papalia, Olds \& Feldman, 2009). Each transition contains the possibility of a critical mass, which is a developmental challenges are usually characterized by the emerging trend of deviant behavior (Ekowarni, 1992). Deviant behavior can be regarded as juvenile delinquency defined as the act by someone who has not grown intentionally violate the law and are known by themselves that the offense was known by law's officers they could get punishment (Sarwono, 2012). Not only breaking the law, the juvenile delinquency also be a violation of the status and/or norms (Aroma \& Suminar, 2012).

Deviant behavior or delinquency in the form of wear and distributing narcotics, extortion, threats, rape, murder, assault, theft, robbery, sexual assault, possession of firearms, gambling, and embezzlement and so forth. Such cases are common underlying case of a teenager into the prison for including unlawful behavior. Institute for Criminal Justice Reform (ICJR) puts the number of children enrolled in a managed by Unit Pelayanan Terpadu yang dikelola Direktorat Jenderal Pemasyarakatan (Ditjen PAS) increased compared to 2016 last. Until June 2017 there were approximately 910 young prisoners custody 895 male and 15 were female, while in January 2016, the number reached 697 
juveniles and rapidly increasing at the end of 2016 reached 907 prisoners. Number of Children who become prisoners (inmates) was approximately the same elevation. Referring to the data in June 2017, there were 2,559 children become prisoners larger than the number of child prisoners in December 2016, amounting to 2,320 children in the 33 region in Indonesia(www.republika.co.id).

Based on the results of an initial interview with the clerk at Lembaga Pembinaan Khusus Anak (LPKA) Tanjung Pati on March 15 th 2017, there were about 29 cases of juvenile delinquency which causes them languishing in custody. The case is diverse, ranging from theft, violence, drugs, and there is also a form of immorality. The age range of the inmates (prisoners) ranging from 13 years to 18 years, with a criminal past that also varies according to the type of violation they do, range from a matter of months up to 5 years of punishment in criminal law.

Penitentiary as coaching container inmates by correctional system (Hermidi, 1996; Yunardhani, 2013) is known so far by people or society is a prison where prisoners for bad people or people who have problems with the law. Although free, ex-prisoners or prisoners were still considered to be the bad guy, is regarded as a trouble maker were always disturbing the public so we need to watch out for (Shofia, 2009). The prisoners regarded as citizens who are prostitutes and less able to provide social participation (Novianto, 2008). This paradigm that still often occurs in the community. As a result, a person's status as prisoner often he felt his life was useless. Social stigma regarding prisoners and also the effect of causing a sense of imprisonment not hopeless and useless emerging and developing of guilt and contempt for inmates, which in turn lead to instability in personal, social, family, work and education. Various problems faced by juvenile inmates, both in terms of personal life, social, learning, and career. This led former juvenile prisoners, which means it is free or out of LPKA as Special Development Institute of the Child is not easy to go back and mingle in society, not least in the field of employment or career.

It'shard to overstate how important finding a first job is for people coming out of prison. It's a boost of selfconfidence, a stabilizing force, and a means of supporting Themselves as they work to Reenter mainstream society"(Business Insider, 2014, getting job after prison, http://www.businessinsider.com/getting-a-jobafter-prison-10/?IR=T.html). In this case, something that is emphasized for individuals coming out of imprisonment in searching or entering a job is the need for self-confidence, a stable and boost power or internal motivation of themselves.

Jobs for teens is something that is socially recognized as a means of (direct / indirect) to meet the satisfaction of the various needs that are not satisfied in full on the previous period (Yusuf, 2006). To be able to do that, then teenagers must learn to develop and maximize their potential, both in the cognitive, affective, psychomotor and conative. This condition must be true for the young prisoner at the LPKA. That is, children who are undergoing training in LPKA need to prepare for the future, especially after undergoing training in LPKA including in the field of career / job.

Someone should be able to do proper planning to acquire the right career choice, which is closely related to self-regulation and information obtained (Parsons in Winkel \& Hastuti, 2004; Bluestein in Purnamasari, 2012). The most effective way to pursue a career is to dig talent or potential as early as possible. As according Santamaria (1991), which explains that before entering a job / career, individuals must first understand him with all their features then then decide what to do and where to go.

Adolescence is the most appropriate time to pursue a career that is by getting to know their talents, interests and ability. So that the person will not only be successful with a perfect career, but also to reach out to the optimum in her life. Through individual career planning is expected to be able to formulate and carry out activities related to career planning future based on an understanding of the opportunities and possibilities that exist in the environment. 
In contrast to the existing reality, the results of the interview on March 15, 2017 with 2 young prisoners in LPKA Tanjung Pati, it is known that they do not know and deciding their future careers after leaving the spot coaching. As said by WF (17 years old) that WF now he had dropped out of school, and do not have a clear purpose after exiting later than LPKA. Things are not much different also delivered by AY (17 years), who said that AY does not have a clear purpose after the finish serving his sentence. Ignorance of juvenile prisoners cannot be separated from the lack of information and knowledge acquired by juvenile inmates of the intricacies of the career issues.

\section{Basic Concepts Career and Career Planning}

1. Career

Getting a decent career or job is the right of all people on this earth, whoever and wherever he is. As stated in the UUD 1945 pasal 27 paragraph (2) that every citizen has the right to work and a decent living for humanity. In that sense, obtaining a decent career or job, and as expected, also one of the most important aspects of a healthy human life wherever and whenever they are. Work has become a necessity to live in this world for everyone. Work becomes an important factor for survival even further is a career in life.

Career Refers to the activities associated with an individual's lifetime ofwork,(Zunker in Suherman, 2009; Hodkinson and Bloomer, 2002) which means that the term career refers to activities related to the individual work of a lifetime. Furthermore, in the business dictionary states that "Careeris the progress and actions taken by a person throughout a lifetime, especially Reviews those related to that person'soccupations"(Businessdictionary.com). According to this understanding is the overall career progression and activity undertaken by a person during its life span (life), which specifically relates to the occupation. In more detail Joseph (2002) defines that a career not just a job, nor occupation. Jobs include preoccupation, occupation and post-occupation during life-span of someone. Career is a sequence / order of position / main job(major)occupied by someone from adolescence to retirement, the life span. Based on this, a career evolved over the span of human life.

\section{Career Planning}

Everything that we do in order to run properly, not necessarily occur instantaneously, but through a continuous process. To be able to run well what we want, and we hope to achieve objectives effectively and efficiently, it takes the name of a plan. Similarly, in a career, so that the goals we want to pursue a career reached then we need something that we call the planning, in that it is planning a career.

Career planning is a picture of a person based on the activity of self-understanding and understanding of the environment to enter an order of life in a particular society changing its development (Munandir, 1999). Furthermore, Santamaria (1991) explains that:

"Career planning is deliberate process of: knowing and understanding ourselves better; Becoming aware of opportunities, choices and the consequences of our choices; identifying options; making decisions about options; developing goals and action plans that will keep us moving in the direction we want to go; and programming work, education and related training and development experiences $"$.

The opinions above illustrates that career planning is a process that begins by getting to know and understand ourselves; then realize their opportunities, and a variety of choices with all its consequences; identify options; make decision; develop goals and make plans that work to keep us from moving in the direction of the desired objectives; to make the program work, education and appropriate training and developing experience. 
Career planning is done has a goal, both short-term goals and long term. According to Dillard's (1985) general purpose of career planning, namely: (1) gain an understanding of self, (2) personal satisfaction, (3) prepare to obtain placement and wage, (4) the effectiveness of the use of time, and (5) in an effort to achieve personal success and career aspired.

Career planning is not an instant process, but is a long-term and complex process, where Dillard (1985) suggested that career planning islifelong.In line with this Hollis (Zen, 1999) also stated career and life planning is life-longpursuit.Furthermore Santamaria (1991) also explains that career planning is not a one time event or something we think we shoul do only once.... It is a longprocess.It is clear from the opinion of career planning is not an activity that is performed once so or something that is done only once, but career planning is a long process and occurs throughout the life span. Planning a good career and a steady, if the individual has the ability in terms of the following: 1) a sense of self, 2) understanding the environment, 3) formulate options, and 4) to formulate a plan of action. (Afdal, 2015).

\section{Basic Concepts Adolescents and Young Prisoners}

\section{Adolescent}

Adolescence is one of the stages or phases of human development. Teenagers are known by the term"adolescence"which means growing up or in development to become adult (Piaget in Hurlock, 1999). According to WHO (Sarwono, 2012), adolescence is a time when people evolved from the first time he showed signs of secondary sexual until she reaches sexual maturity; individuals experiencing psychological development and the identification of patterns of children reach adulthood; a shift from full socio-economic dependence to the state of a relatively more independent. In the span of several changes and developments within the individual that covers developments in the biological, psychological, moral, and religious as well as changes related to psychosexual development, and also changes in relationships with parents and their ideals (Santrock 1998; Papalia, Olds \& Feldman, 2009).

During life span, individuals undergo a developmental task that is known as the task of human development. The task of development is a task that appears at or around a specific time period of the life of the individual, which if successful will lead to a sense of happiness and leads to success in implementing his later work (Hurlock, 1999). Cole (John, 2013) classify the tasks of adolescent development in nine categories, namely: (1) emotional maturity, (2) to consolidate the interests heterosexual, (3) social maturity, (4) the emancipation of family control, (5) the maturity of intellectual, (6) employment, (7) using leisure time appropriately, (8) have a philosophy of life, and (9) of self-identification.

Special tasks in the areas of career development, Herr, Cramer \& Niles (2004) explains that"Goalsfor career development in adolescent in career planning is; skills to make-decisions, skills in career planning". From this it is understood that the teenager claimed to have the ability to make decisions and the ability to make career planning.

2. Young Prisoners

During development of adolescents who experienced many changes and developments, often teenagers fall into a negative direction, where they perform actions that they should not do or perform deviant behavior. Deviant behavior can be regarded as the delinquency defined by Sarwono (2012) as an act by a person who intentionally violates minors' law and known by the child itself that the deed was known to law officers he could get punishment. 


\section{Method}

The population in this study adolescents who are in LPKA Tanjung Pati totaling 32 people. The sampling technique used is total sampling, where the number of samples is equal to the number of population. The data collection techniques used were interviews and questionnaires young prisoner career planning

\section{Results and Discussion}

Table 1. Overview Prisoners Problems Adolescent in Career Planning

\begin{tabular}{ccccc}
\hline No. & Category & Interval & Frequency & $\%$ \\
\hline 1 & Extremely High & $58-65$ & 17 & 51.51 \\
2 & High & $46-57$ & 11 & 33,33 \\
3 & Pretty Much & $35-45$ & 4 & 12.12 \\
4 & Low & $24-34$ & 0 & 0.00 \\
5 & Very Low & $13-23$ & 0 & 0.00 \\
\hline
\end{tabular}

Based on the inventory deployment career field problems at 32 young prisoners, it is known that; young prisoners who have problems with the career planning at a very high category as many as 17 people with a percentage of $51.51 \%$, in other words more than half the number of juvenile inmates have problems in planning a career in a very high category. Juvenile inmates who have career problems in the high category of 11 people with a percentage of $33.33 \%$. Juvenile inmates who have career problems in the category of pretty much 4 people with 12:12\% percentage. From these figures it can be concluded that juvenile inmates problematic in the field of career planning. Aspects of career planning include aspects of self-understanding, understanding of the work environment, formulating options, and an action plan.

Some problems of young prisoners in planning a career, are: (1) Has not been able to plan the future. At the age of teens one of the capabilities in the development of the duties must be dominated by teenagers, namely the ability to plan a career/job desired. (2) Do not know the talent themselves for the career/job. Understand yourself by knowing the talent and potential is the initial aspect that should be known by young people in career planning. (3) The worry about not being able to plan for the future. (4) Lacking an extensive knowledge about employment and the ins and outs of the job. It relates to an understanding of the work environment includes the kinds of jobs available in the field, the ins and outs of the job, what are the requirements a must-have for a career/job, and others. (5) having problems about the future. (6) A doubt about the opportunity gain employment in accordance with the education and training that followed after in LPKA. (7) The fearness with the shadow of the future because of the lack of education and training. Lack of understanding of the self, understanding of the environment, the formulation of career choices/job that is not yet clear, and the plan of action is not yet clear cause young prisoners experiencing problems with future and afraid to imagine the future that will be traveled. These problems affect career planning by young prisoners.

\section{Conclusions and Discussion}

Adolescence is a transition period from the age of children to adulthood. During his adolescent development tasks often fall into negative direction which caused them perform acts that violate the 
law so that a sanctioned form of criminal punishment. One of the tasks of development must be passed by a teenager is the task of selecting and planning the work / career for the future. However, various conditions faced by teenagers who were in the Special Child Development Institute (LPKA) including a lack of information about careers in the can by young prisoners causing them trouble to plan for their future careers. In general, juvenile inmates in Tanjung Pati LPKA problematic in career planning.

\section{Acknowledgments}

The authors thanks to Prof. Dr. A. Muri Yusuf, M.Pd., and Dr. Afdal, M.Pd., Kons., As a mentor who has provided guidance, advice and input in the writing of this article.

\section{References}

Aroma, I. S., \& Suminar, D. R. (2012). Hubungan antara tingkat kontrol diri dengan kecenderungan perilaku kenakalan remaja. Jurnal Psikologi Pendidikan dan Perkembangan, 1(2), 1-6.

Afdal. (2015). "Model Bimbingan Karier Kolaboratif dalam Memantapkan Perencanaan Karier Siswa SMA (Studi Bimbingan Karier Guru BK/Konselor dengan Orang tua dalam Memantapkan Perencanaan Karier Siswa SMA Negeri di Kota Payakumbuh)". Disertasi tidak diterbitkan. Bandung: UPI.

Batubara, J. R. (2016). Adolescent development (perkembangan remaja). Sari Pediatri, 12(1), 21-9.

BusinessInsider (2014).http://www.businessinsider.com/getting-a-job-after-prison-10/?IR=T (online). Diakses 20 Mei 2017.

Dillard, J. M. (1985). Life long Career Planning. Columbus, Ohio: Bell \& Howell Company.

Ekowarni, E. (1992). Kenakalan Remaja: Suatu Tinjauan Psikologi Perkembangan. Buletin Psikologi, 1(2), 24-27.

Hermidi, B. (1996). “Beberapa Aspek Sistem Pemasyarakatan dalam Konteks Sistem Peradilan Pidana". Disertasi:UNDIP.

Herr, E. L., Cramer, S. H., \& Niles, S. G. (2004). Career Guidance and Counseling Through the Lifespan: Systematic approaches. Boston: Pearson.

Hodkinson, P., \& Bloomer, M. (2002). Learning careers: conceptualizing lifelong work-based learning. Working to learn: Transforming learning in the workplace, 29-43.

Hurlock, E. B. (1999). Psikologi Perkembangan: Suatu pendekatan sepanjang rentang kehidupan. Alih bahasa oleh Istiwidayanti dan Soedjarwo Jakarta: Erlangga.

Jahja, Y. (2013). Psikologi Perkembangan. Jakarta: Kencana Media Grup.

Munandir. (1999). Program Bimbingan dan Konseling di Sekolah. Jakarta: Depdikbud, Ditjen Dikti.

Nindya, P. N., \& Margaretha, R. (2012). Hubungan antara kekerasan emosional pada anak terhadap kecenderungan kenakalan remaja. Jurnal Psikologi Klinis dan Kesehatan Mental, 1(02).

Novianto, P. (2008). “Dinamika Konsep Diri Pada Narapidana Menjelang Bebas Di Lembaga Pembinaan Khusus Anak Sragen". Disertasi. Surakarta: Universitas Muhammadiyah.

Papalia, D. E., Olds, S. W., \& Feldman, R. D. (2009). Human Development, ed 10th. New York: McGrawHill.

Purnamasari, A. (2012). Efektivitas Pelatihan Perencanaan Karir Untuk Meningkatkan Kejelasan Arah Pilihan Bidang Minat Karir Pada Mahasiswa Semester III Fakutas Psikologi. HUMANITAS (Jurnal Psikologi Indonesia), 3(1), 38-49.

Republika (2017).http://www.republika.co.id/berita/nasional/hukum/17/07/21/otfugz-icjr-jumlahtahanan-anak-di-indonesia-meningkat-pesat (online). Diakses 20 Mei 2017.

Santamaria, J. O. (1991). Career Planning Workbook. Philippines : P.T. Martin Publishing Services.

Santrock, J. W. (1998). Adolescence. New York: McGraw-Hill Companies. 
Sarwono, S. W (2012). Psikologi Remaja. Jakarta: PT. Raja Grafindo Persada.

Shofia, F. (2009). "Optimisme masa depan narapidana". Disertasi. Surakarta: Universitas Muhammadiyah.

Suherman, U. (2009). Konseling Karir Sepanjang Rentang Kehidupan. Bandung: UPI.

Tohirin. (2007). Bimbingan dan Konseling di Sekolah dan Madrasah (Berbasis integrasi). Jakarta: PT Raja Grafindo Persada.

Undang-Undang Dasar 1945.

Undang-Undang No. 12 Tahun 1995 tentang Pemasyarakatan.

Undang-Undang Nomor 3 Tahun 1997 tentang Pengadilan Anak

Walgito, B. (2010). Bimbingan + Konseling [studi \& karier]. Yogyakarta: ANDI OFFSET

Yunardhani, R. (2013). Efektifitas Lembaga Pembinaan Khusus Anak di Indonesia. Sosiologi: Jurnal Ilmiah Kajian Ilmu Sosial dan Budaya, 15(2).

Yusuf, A. M. (2002). Kiat Sukses dalam Karier. Jakarta: Ghalia Indonesia.

Yusuf, S. (2006). Psikologi Perkembangan Anak dan Remaja. Bandung: Remaja Rosdakarya.

Zen, M. (1999). "Perencanaan Karier Siswa dalam Hubungannya dengan Konsep Diri dan Pemahaman Informasi Karier". Tesis tidak diterbitkan. Padang: UNP. 